\title{
MoRPHOLOGICAL AND DYNAMiCAL CHARACTERIZATION OF TAMANDARÉ BAY, PERNAMBUCO - BRAZIL
}

\author{
Daniele Barbosa Portella \\ FÁtima LÚCIA DE BRITO dos SANTOS \\ Tereza Cristina Medeiros de Araúuo
}

UFPE - Departamento de Oceanografia

\begin{abstract}
SUMARY
A temporal assessment of variations of the beach topographical profile was made at Tamandaré Bay, in order to understand the behavioural patterns and the impacts of erosive processes underway in the area. The analysis of four perpendicular contours, measured on ebb tide just before spring tide, evenly distributed along the beach's length were made. Beach morphological and dynamical classification has also been carried out. The results strongly suggest a general erosive trend within the bay. Grain size analysis resulted in the predominance of the sand fraction. The Dean parameter has revealed a marked seasonally in the morphology of the beach profile and has resulted in an intermediary type beach profile in Tamandare Bay, except for contour 2, where this profile was reflective.
\end{abstract}

\begin{abstract}
Pernambuco State coastal zone is highly populated and developed. Coastal erosion is a problem of major concern in this area. Recently it has been intensified due to the lack of knowledge about operating erosive processes. The aim of this work was to identify the presence of any erosive process underway in Tamandaré Bay, an area of about $24 \mathrm{~km}^{2}$ at Pernambuco's southern littoral. Field work have been carried out in monthly surveys from February of 1999 to January of 2000, consisting of 4 contours evenly distributed along the beach just before spring tide during ebb tides. Bench work involved both grain size analysis and the beach morphological and dynamical classification. The data collected suggest an erosive trend for Tamandare Bay, with a general volume loss of about $125.67 \mathrm{~m}^{3} / \mathrm{m}$, with sand being the dominant sediment size. These results seems to confirm the seasonally of beach profiles, with the exception of contour 3, which showed the opposite behaviour in terms of variation of sediment volume, but has exhibited the same trend for grain size. Tamandaré Bay shows a beach profile of an intermediate type, with the exception of contour 2, which was reflective. These results does not completely explain the behaviour of the sediments in this bay. New surveys should be encouraged in order to identify the patterns of longshore drift, sediment transport and to define whether the actual erosive process is a natural phenomena or not.
\end{abstract}

Key Words: Coastal Erosion;- Beach Profile; Grain Size

Tropical Oceanography, Recife, v. 29, n. 1, p. 79-86, 2001. 


\section{INTRODUCTION}

Pernambuco State, on the eastern most portion of the Brazilian Northeast is located at $7^{\circ} 15^{\prime} 45^{\prime \prime}$ to $9^{\circ} 28^{\prime} 18^{\prime \prime} \mathrm{S}$ and $34^{\circ} 48^{\prime} 35^{\prime \prime}$ to $41^{\circ} 19^{\prime} 54^{\prime \prime} \mathrm{W}$. With an area of $98,281 \mathrm{~km}^{2}$ and a resident population of 7,918,344 inhabitants (Pernambuco, 1991; IBAMA, 1993; IBGE, 2001). The coastline has $187 \mathrm{~km}$, and the coastal region has an area of $4,410.0 \mathrm{~km}^{2}$. The population in this region was $3,547,893$ inhabitants $\left(707 \mathrm{hab} / \mathrm{km}^{2}\right)$ in 2000 (MMA, 1995; IBGE, 2001).

Pernambuco coastline has a very low topographic relief which changes from a plain region, sometimes bellow sea level, by the coast, to small hills which vary in altitude from 0 to 650 metres. The low relief is broken only by Santo Agostinho Cape in the southern littoral, Barra de Catuama and the Ponta de Pedras hills in the northern littoral. This low topographic relief helps the development of mangrove ecosystems and results in a great deal of flooding (FIDEM, 1987a, 1987b; Pernambuco, 1991; IBAMA, 1993). This region is characterised by the Barreiras (rocky cliffs) sandstone reefs, narrow coastal plains with sandy beaches and broad mangrove forests along rivers and estuaries (Pires-Filho and Cycon, 1987).

The average rainfall is $1,800 \mathrm{~mm} / \mathrm{p}$.a., distributed between 9 to 12 months during the year. The rainy season usually occurs between March and August. In the southern section of the coastal plains the vegetation is characterised as humid forest, where small patches of the Atlantic Rain Forest can still be found. There are many sensitive ecosystems like mangroves and restingas in the coastal zone, which are currently under severe human pressure. Even being protected by federal and state laws these ecosystems are still continuously threatened by human activities such as estate fragmentation and dealing, expansion of sugarcane fields, human and industrial settlement.

Coastal erosion has been a major concern in the coastal degradation process since it usually leads to estate loss (Lira, 1997). Due to unplanned urban development many sites along Pernambuco coast line are showing signs of progressive marine erosion which may vary from moderate to severe. Nevertheless, an accurate and precise diagnosis is still not available. The absence of sufficient data necessary to comprehend the causes of such erosive process neither locally or regionally, is leading to the aggravation of the coastal erosion problem in the state (Lira, 1997).

The erosive problem in Pernambuco state has caused a great deal of concern to the State Government, Municipalities and to the local population, the most affected by this problem. However, the measures adopted so far have showed to be insufficient to solve the problem (Lira, 1997).

This work aimed to identify the presence of erosive processes and its causes in Tamandaré Bay, southern littoral of Pernambuco, and to make a contribution for a better coastal planning in the area.

\section{METHOD}

This study has consisted of field and laboratory work. Field work has been carried out at Tamandaré Bay (Figure 1), located about $110 \mathrm{~km}$ south of Recife, Pernambuco state's capital $\left(08^{\circ} 44^{\prime} 30^{\prime \prime}\right.$ to $08^{\circ} 47^{\prime} 30^{\prime \prime} \mathrm{S}$ and $030^{\circ} 05^{\prime}$ to $\left.037^{\circ} 07^{\prime} \mathrm{W}\right)$. The geographical limits of the bay are Pontal do Lira at the north, Ilhetas Point at the south, coral reef lines to the east and the coastal plains to the west.

Four contours have been carried out along the beach (numbered as 1 to 4 ), in the southnorth direction. The contours have been realised at the coordinates $08^{\circ} 46.408^{\prime} \mathrm{S}$ and $035^{\circ} 06.345^{\prime} \mathrm{W}$; $08^{\circ} 46.000^{\prime} \mathrm{S}$ and $035^{\circ} 06.334^{\prime} \mathrm{W} ; 08^{\circ} 45.615^{\prime} \mathrm{S}$ and $035^{\circ} 05.979^{\prime} \mathrm{W}$ and $08^{\circ} 45.522^{\prime} \mathrm{S}$ and

Tropical Oceanography, Recife, v. 29, n. 1, p. 79-86, 2001. 
$035^{\circ} 05.760^{\prime} \mathrm{W}$, respectively. The contours aimed to show details about the factors controlling the beach profile gradient (Figure 1).

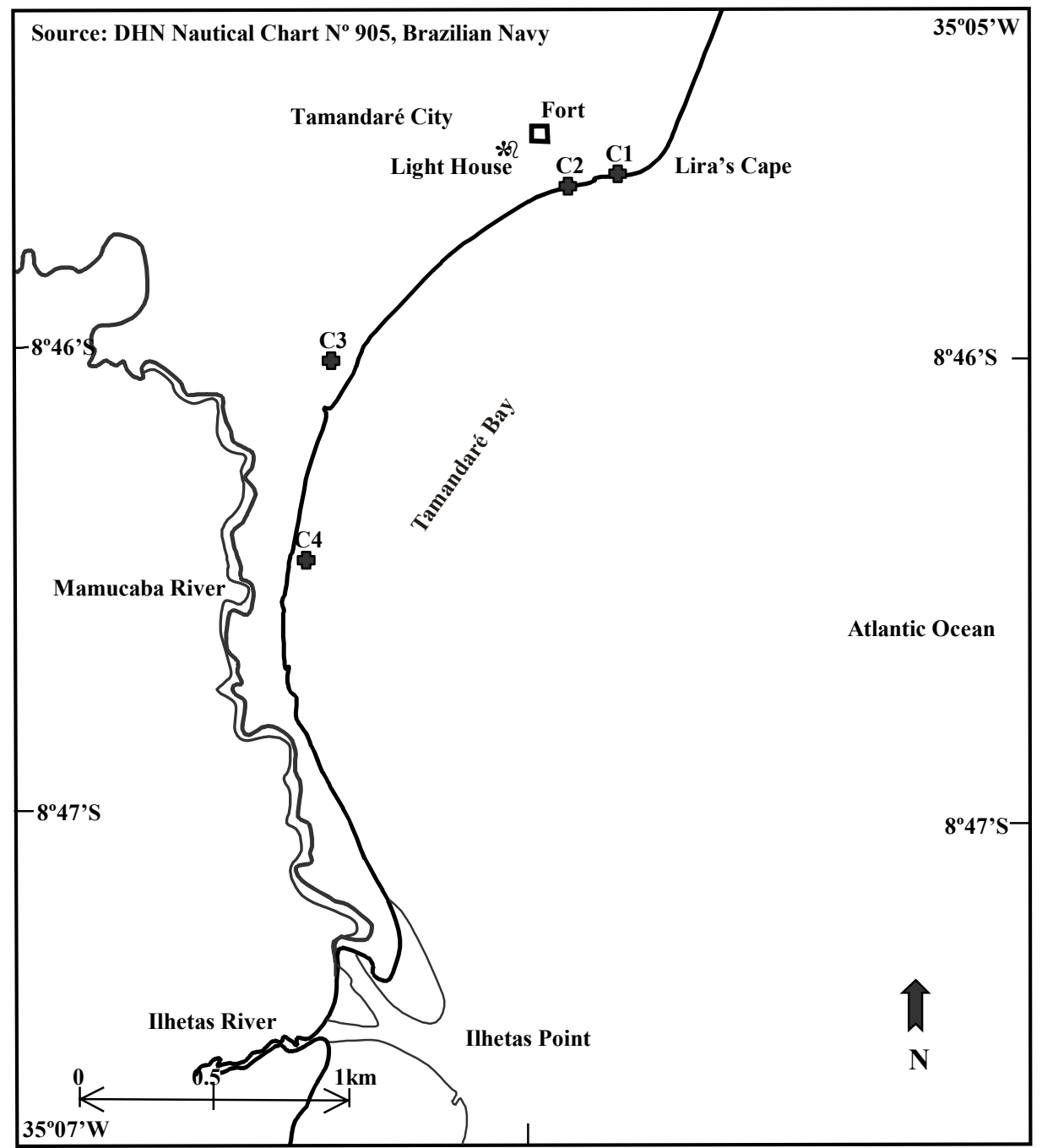

Figure 1 - Tamandare Bay, Pernambuco State, Brazil. The bay is limited to the east by lines of shallow sandstone and coral reefs which show during low tide.

The field survey was made monthly, from February 1999 through January 2000, on each contour. The surveys were carried out just before each spring tide, during the ebb tide using the topographic level Zeiss Ni50 and topographic view. Also, 48 measurements of the shoreface inclination and 144 samples of beach surface sediments (backshore - BS, beach - B and foreshore FS, on each profile measured) were taken.

In the laboratory samples were submitted to grain size analysis with sieves with $1 \phi$ of interval and the results have been expressed as mean and standard deviation.

The morphologic and dynamic classification has followed the model by Wright \& Short (1984) using the Dean Parameter $(\Omega)$ (Table 1) defined as:

Tropical Oceanography, Recife, v. 29, n. 1, p. 79-86, 2001. 


$$
\Omega=\frac{H_{b}}{w_{s} T}
$$

where: $\quad \mathrm{B}_{\mathrm{b}}=$ the wave height at the breaking zone

$W_{\mathrm{s}}=$ speed of the grain sedimentation

$T=$ wave period

The wave height was obtained by visual observations with the help of the topographic level (Zeiss Ni50) and the topographic view.

Based on the field data it has been calculated the relative position at each point at each contour, with the zero position being designated as the reference level. The plots of the beach profiles have been made with the help of the MS EXCEL software and the volume of sediments removed or deposited was calculated with the help of SURFER 32 Golden Software.

Table 1 - Balance relations between beach conditions and $\Omega$ (Hoefel, 1998).

\begin{tabular}{l|l}
\hline Beach Conditions & $\Omega$ \\
\hline Reflective & $<1.50$ \\
Ridge and Runnel/Low Tide Terrace & 2.40 \\
Transverse Bar and Rip & 3.15 \\
Rhythmic Bar and Beach & 3.5 \\
Longshore Bar-Trough & 4.7 \\
Dissipative & $>5.50$ \\
\hline
\end{tabular}

\section{RESULTS AND CONCLUSIONS}

The analysis of winter (rainy season) and summer (dry season) beach profiles for Tamandaré Bay (Table 2) has showed that, at least 3 contours have apparently followed the main wind system in Pernambuco southern littoral. The winds are also classified as winter and summer systems, in the same way as beach profiles. During the summer months, from October to March, the winds blow to the East. Winter winds, from April to September, blow to the Southeast (data from SUAPE Harbour) (Lira, 1997).

The data have revealed an erosive trend for Tamandaré Bay (Table 3), where the total volume loss has reached $125.67 \mathrm{~m}^{3} / \mathrm{m}$ for the whole bay (Figures 2, 3, 4 and 5).

The grain size analysis has showed that sand is predominant (Table 4) and it seemed to confirm the summer and winter beach profiles patterns showed on Table 2, except for contour 3. Contour 3 showed an opposite behaviour for sediments movement, but had the same trend concerning the grain size results. The grain sorting analysis has shown that when the grain size increased the sorting diminishes.

The Dean Parameter $(\Omega)$ (Table.1) and the comparative analysis of the morphological and dynamical profiles proposed by Wright and Short (1984) has resulted in an intermediary type beach profile in Tamandaré Bay, except for contour 2, where this profile was reflective.

These results seems to confirm an erosive trend which usually occurs at the promontories and capes. However, the same can not be applied to contour 2, which has shown an intense erosive process. For this reason, it is suggested that new surveys should be made in order to determine the longshore drift. It is also suggested that a new contour should be added further south, beyond the Mamucabas River mouth. We believe that these new data would be able to establish how and where

Tropical Oceanography, Recife, v. 29, n. 1, p. 79-86, 2001. 
the sediments are transported and settled. This complementary information may also be useful to determine if the present erosive process taking place in Tamandare Bay is part of the natural dynamic of this beach.

Table 2 - Summer and winter beach profiles for each contour on Tamandaré Bay, Pernambuco, Brazil.

\begin{tabular}{c|c|c}
\hline \multirow{2}{*}{ Beach Contour } & \multicolumn{2}{|c}{ Beach Profile } \\
& Summer System & Winter System \\
\hline C1 & March & September \\
C2 & April & October \\
C3 & October & March \\
C4 & March & October \\
\hline
\end{tabular}

Table 3 - Annual sediment movement for each contour on Tamandaré Bay, Pernambuco, Brazil.

\begin{tabular}{c|l|l|l}
\hline Beach & \multicolumn{3}{|c}{ Sediments Volume $\left(\mathbf{m}^{3} / \mathbf{m}\right)$} \\
Contour & Total Loss & Total Gain & Final Volume \\
C1 & 21.16 & 37.78 & +16.62 (gain) \\
C2 & 115.34 & 1.20 & -113.35 (loss) \\
C3 & 22.26 & 59.87 & +37.61 (gain) \\
C4 & 84.91 & 18.36 & -66.55 (loss) \\
\hline
\end{tabular}

Table 4 - Mean grain size sediments $(\phi)$ for each contour on Tamandaré Bay, Pernambuco, Brazil.

\begin{tabular}{l|l|l}
\hline \hline Beach & \multicolumn{2}{|c}{ Grain Size $(\phi)$} \\
Contour & \multicolumn{2}{|c}{} \\
& Summer & Winter \\
\hline C1 & 2.33 & 1.40 \\
C2 & 2.01 & - \\
C3 & 2.64 & 2.10 \\
C4 & 2.74 & 2.48 \\
\hline
\end{tabular}

Tropical Oceanography, Recife, v. 29, n. 1, p. 79-86, 2001. 


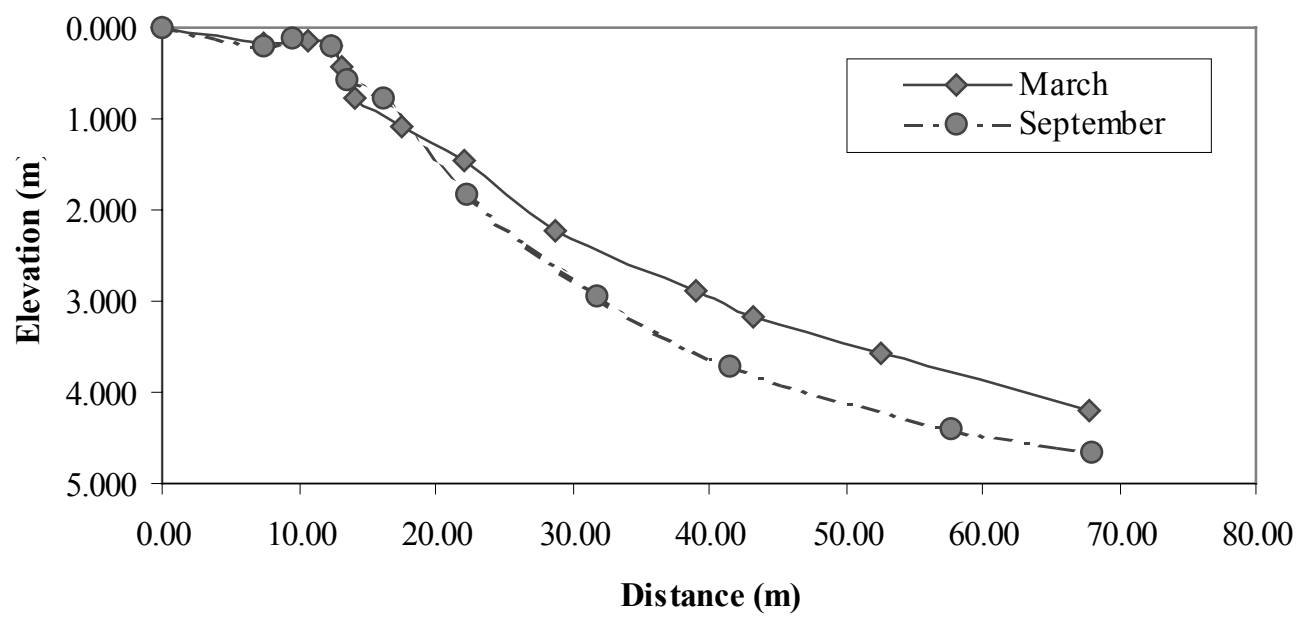

Figure 2 - Summer and Winter Beach profiles of Contour 1 in Tamandaré Bay, Pernambuco State, Brazil.

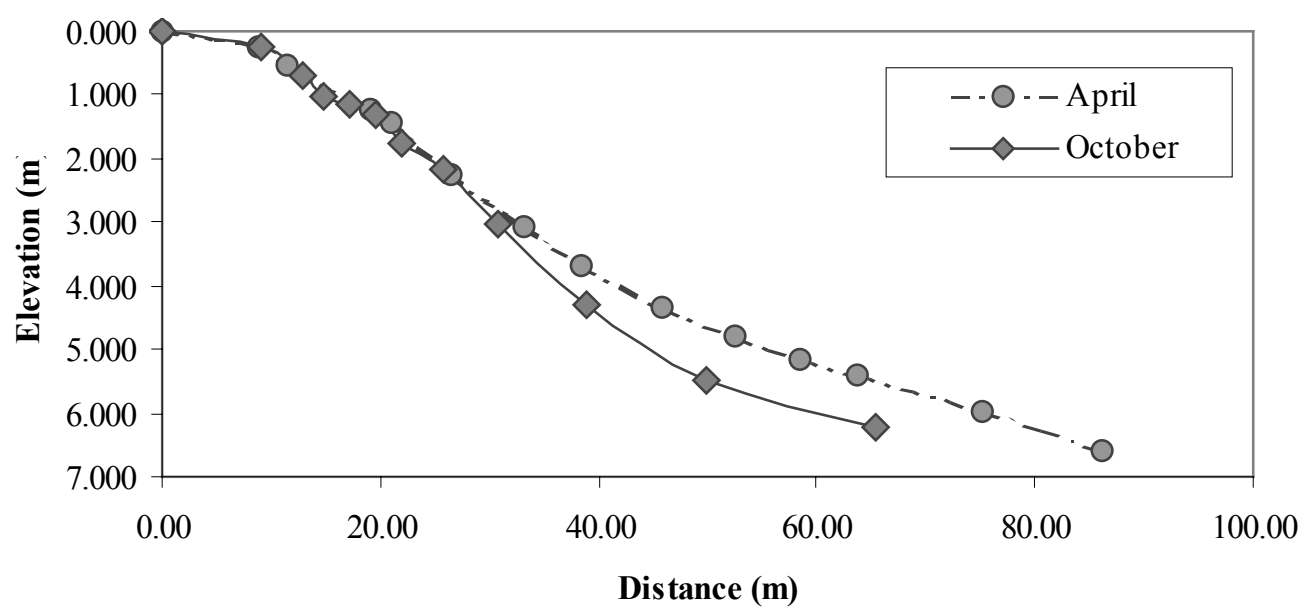

Figure 3 - Summer and Winter Beach profiles of Contour 2 in Tamandaré Bay, Pernambuco State, Brazil.

Tropical Oceanography, Recife, v. 29, n. 1, p. 79-86, 2001. 


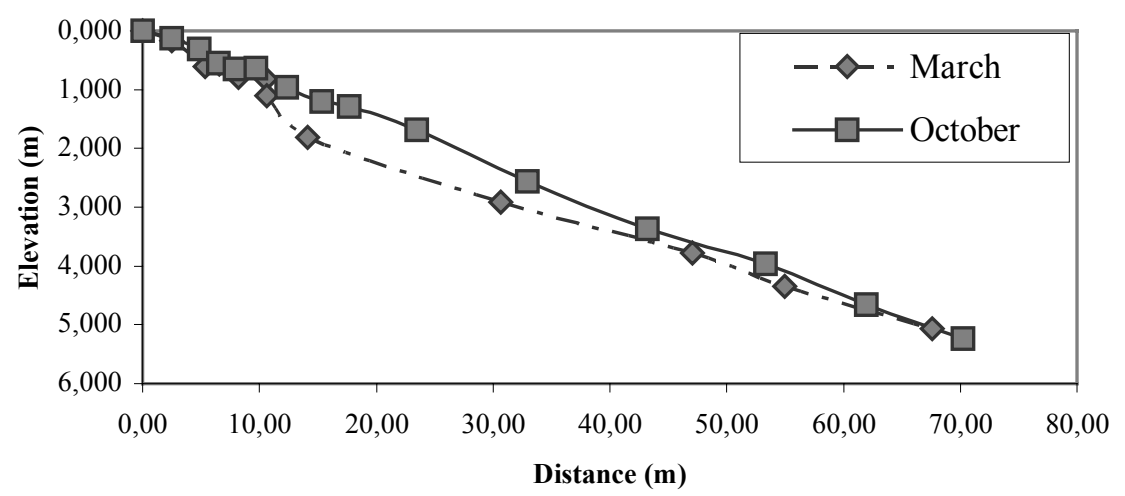

Figure 4 - Summer and Winter Beach profiles of Contour 3 in Tamandaré Bay, Pernambuco State, Brazil.

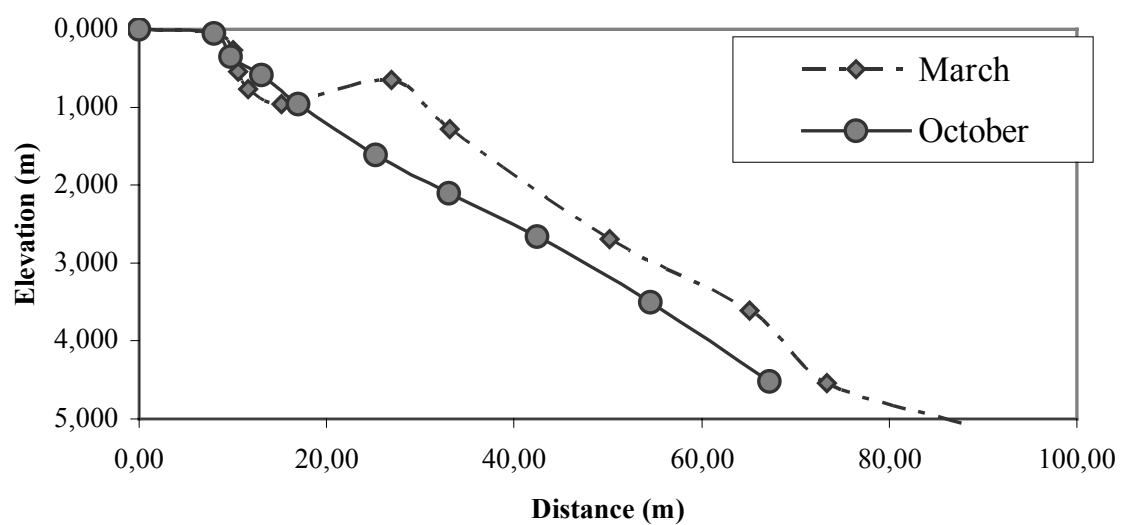

Figur 5 - Summer and Winter Beach profiles of Contour 4 in Tamandaré Bay, Pernambuco State, Brazil.

\section{REFERENCES}

FIDEM - Fundação de Desenvolvimento Municipal. "Região Metropolitana do Recife: Reservas Ecológicas". Série de Desenvolvimento Urbano e Meio Ambiente. Recife. Brazil. 1987a

FIDEM - Fundação de Desenvolvimento Municipal. "Protection of the Estuarine Areas". Série de Desenvolvimento Urbano e Meio Ambiente. Recife. Brazil. 1987b

Hoefel, F. G. Morfodinâmica de Praias Arenosas Oceânicas: Uma revisão bibliográfica. Itajaí. Univali, 92p. 1998

IBAMA - Instituto Brasileiro do Meio Ambiente e dos Recursos Naturais Renováveis. Diagnóstico do Setor Florestal do Estado de Pernambuco. Projeto PNUD/ FAO/ IBAMA/ BRA/ 87/ 007. Recife. Governo Federal, 72p. 1993

Tropical Oceanography, Recife, v. 29, n. 1, p. 79-86, 2001. 
IBGE - Instituto Brasileiro de Geografia e Estatística 2001. Censo Demográfico 2000 - Resultados Preliminares. Disponível em:

http:/www.ibge.net/ibge/estatistica/populacao//censo2000/default.shtm. Acesso em 31 de janeiro de 2002.

LIRA, A. R. do A. Caracterização Morfológica e Vulnerabilidade do Litoral entre as Praias da Enseadinha e Maria Farinha, Paulista - PE. Dissertação de Mestrado. 96p. 1997

MMA - Ministério do Meio Ambiente. Perfil dos estados litorâneos do Brasil: subsídios à implantação do Programa Nacional de Gerenciamento Costeiro/ Coordenações Estaduais do Gerenciamento Costeiro. Brasília: Programa Nacional do Meio Ambiente. v. 9, p. 1-211. (Gerenciamento Costeiro). 1995

PERNAMBUCO. Perfil Ambiental do Estado de Pernambuco: Um documento para a ABEMA Associação Brasileira de Entidades de Meio Ambiente. Recife. Governo do Estado. 1991

PIRES-FILHO, I. D. A.; CYCON, D.E. "Planning and Managing Brazil's Coastal Resources". Coastal Management. v. 15, n.1, p. 61-74, 1987

WRIGHT, L. D.; SHORT, A. D. Morphodynamic Variability of surf zones and beaches: a sysnthesis. Marine Geology, v. 56, p. 93-118, 1984.

Tropical Oceanography, Recife, v. 29, n. 1, p. 79-86, 2001. 